\title{
PENGELOLAAN E-CONFERENCE DENGAN APLIKASI OPEN CONFERENCE SYSTEM: UPAYA PENGEMBANGAN PENERBITAN PROSIDING ONLINE DI INDONESIA
}

\author{
Wahid Nashihuddin*, Dwi Ridho Aulianto*
}

Pengutipan: Nashihuddin, W., dan Aulianto, D. R. (2017). Pengelolaan e-conference dengan aplikasi open conference system: upaya pengembangan penerbitan prosiding online di Indonesia. Khizanah Al-Hikmah : Jurnal Ilmu Perpustakaan, Informasi, dan Kearsipan, 5(1), 29-49.

DOI: http:/ /dx.doi.org/10.24252/kah.v5i1a3

*Pusat Dokumentasi dan Informasi Ilmiah - LIPI Jl. Jend. Gatot Subroto No.10, Jakarta Selatan 12710 mamaz_wait@yahoo.com

\section{ABSTRAK}

Kajian ini bertujuan untuk menjelaskan dan mengetahui: (1) ketentuan umum penyelenggaraan konferensi dan penerbitan prosiding hasil konferensi; (2) jumlah prosiding ber-ISSN yang terbit di Indonesia; (3) upaya pengembangan penyelenggaraan e-conference dan penerbitan e-proceeding di Indonesia; dan (4) tahapan pengelolaan e-conference dengan OCS. Hasil kajian ini, yaitu: (1) dalam pengelolaan prosiding, penyelenggara konferensi harus memperhatikan lingkup konferensi dan ketentuan penerbitan prosiding, baik untuk skala nasional maupun internasional; (2) jumlah penerbitan prosiding di Indonesia relatif masih rendah, terlihat pada jumlah terbitan prosiding ber-ISSN hanya sejumlah 997 prosiding dan dari jumlah tersebut hanya diketahui sekitar 63 prosiding yang sudah diterbitkan dalam versi online; (3) pemerintah dan penyelenggara konferensi perlu berupaya keras dan memiliki komitmen yang tinggi untuk menggalakan penyelenggaraan e-conference dan penerbitan eproceeding di Indonesia; dan (4) pengelolaan e-conference dengan OCS membutuhkan sumber daya organisasi yang memadai dan perencanaan yang matang agar menghasilkan publikasi yang berkualitas.

Kata kunci: Konferensi, prosiding, open conference system, public knowledge project

\section{ABSTRACT}

This study aims to describe and determine: (1) the general provisions of the conference and the proceeding publication of conference resulting; (2) the number of proceedings had ISSN that published in Indonesia; (3) efforts to develop the conference holding and e-proceedings publication in Indonesia; and (4) the management steps of e-conference with OCS. The results of this study: (1) in management of proceedings, the conference organizers have to see the conference scope and the provisions of proceedings publication, both for national and international scale; (2) the number of proceedings publishing in Indonesia was low relatively, there are seen in the publication number of ISSN proceedings only 997 proceedings and of that number known to about 63 proceedings only that have been published in the online version; (3) the government and the conference organizers have to work and have a commitment hardly to promote the e-conferencing holding and e-proceedings publishing in Indonesia; and (4) management of e-conference with OCS needs adequate organization resources and obvious planning in order to produce a qualified publication.

Key words: Conference, proceeding, open conference system, public knowledge project 


\section{PENDAHULUAN}

Selain jurnal, makalah hasil konferensi atau seminar juga menjadi salah satu publikasi ilmiah yang menjadi output lembaga, khususnya di institusi pendidikan tinggi dan lembaga penelitian dan pengembangan (litbang). Pada lembaga tersebut, kegiatan konferensi, seminar, dan pertemuan ilmiah sejenisnya telah menjadi agenda kegiatan rutin tahunan (minimal satu tahun sekali). Saat ini, berbagai istitusi pendidikan dan litbang di Indonesia berlomba-lomba menyelenggarakan konferensi dan pertemuan ilmiah sejenisnya guna meningkatkan kerjasama penelitian ataupun kegiatan ilmiah lainnya, baik dalam skala nasional maupun internasional. Selain itu, publikasi hasil konferensi juga menjadi menjadi salah satu indikator suatu lembaga itu masih eksis. Ketika hasil konferensi diterbitkan dan dipublikasikan ke media cetak dan elektronik, animo masyarakat untuk menggali informasi publikasi hasil konferensi akan semakin tinggi. Dalam hal ini menemukan sumber informasi yang ada di makalah/prosiding untuk bahan penelitian atau penulisan ilmiah.

Pada penyelenggaraan konferensi, tentunya institusi/lembaga tidak hanya menginginkan kegiatannya berjalan lancar dan sukes, tetapi juga menghasilkan suatu publikasi ilmiah yang berkualitas, apakah berupa kumpulan makalah lengkap ataupun prosiding yang dibukukan. Hal tersebut tentunya akan membutuhkan anggaran kegiatan yang relatif besar dan sumber daya organisasi yang memadai guna kelancaran dan kenyamanan pelaksanaan konferensi. Sebagai output lembaga diharapkan setiap informasi yang tercantum prosiding dapat diakses seluas-luasnya oleh masyarakat global dengan mudah dan cepat serta memberikan dampak besar dalam kemajuan iptek. Agar konten informasi prosiding dapat diakses lebih luas, mudah, dan cepat oleh masyarakat, maka harus diterbitkan secara elektronik dan online. Terkait dengan penyelenggaraan konferensi dan penerbitan makalah/prosiding ini sudah ada suatu aplikasi online untuk hal tersebut, yaitu Open Conference System (OCS).

Software OCS bersifat open source dan open access, serta mudah dikelola konten dan fiturnya sesuai kebutuhan penyelenggara konferensi. OCS merupakan salah satu sistem online yang terinstal secara tunggal tetapi dapat digunakan untuk berbagai host kegiatan konferensi, misalnya "PKP Scholarly Publishing Conference" and "Special Topics in Computing" atau PKP Scholarly Publishing Conference 2007" and "PKP Scholarly Publishing 2008". Melalui OCS, sistem penjadwalan kegiatan konferensi juga dapat diatur sesuai waktu dan kebutuhan yang telah ditetapkan oleh pihak penyelenggara konferensi. Terkait dengan pengelolaan situs dan konten $e$ conference, sudah ada administrator situs (site administrator) dan manajer konferensi (conference manager). Administrator situs bertanggung jawab menginstal dan menciptakan situs konferensi, sedangkan manajer konferensi bertanggung jawab mengatur jadwal kegiatan konferensi (PKP, 2008). Melalui OCS, informasi penyelenggaraan konferensi dan penerimaan naskah/makalah call for paper dapat dilakukan secara online.

Permasalahannya adalah pengelolaan e-conference di Indonesia belum semarak seperti pengelolaan e-journal. Hal tersebut tentunya menjadi tugas kita bersama, baik pemerintah maupun penyelenggara konferensi. Pemerintah, dalam hal ini Kementrian Riset dan Teknologi-DIKTI; Perpustakaan Nasional; atau Lembaga 
Ilmu Pengetahuan Indonesia, perlu berupaya semaksimal mungkin untuk menggalakkan program $e$-conference untuk penerbitan prosiding elektronik $(e-$ proceeding). Hal tersebut dapat dilakukan sebagaimana mewajibkan pengelola jurnal untuk menerbitan e-journal jika ingin terakreditasi terbitannya. Upaya ini perlu dilakukan mengingat publikasi jurnal dan prosiding memiliki beberapa persamaan, yaitu sama-sama hasil kajian atau penelitian yang melalui proses editing dan peer-review; serta memiliki informasi mutakhir di bidang iptek. Sedangkan perbedaannya hanya pada waktu terbitnya, jurnal harus terbit secara periodik (berkala) dan prosiding tidak harus terbit secara periodik (tergantung pada kemampuan lembaga/organisasi.

Berdasarkan uraian di atas, kajian ini membahas empat hal, yaitu: (1) apa saja yang menjadi ketentuan penyelenggaraan konferensi dan penerbitan prosiding hasil konferensi; (2) berapa jumlah prosiding ber-ISSN yang terbit di Indonesia; (3) bagaimana upaya untuk mengembangkan kegiatan konferensi di Indonesia dengan sistem e-conference?; dan (4) bagaimana pengelolaan e-conference dengan OCS. Agar bahasan lebih fokus untuk menjawab dua hal tersebut, ditetapkan pembatasan kajian, yaitu: pengelolaan $e$ conference tidak mambahas masalah teknis kepanitiaan konferensi dan tahapan operasional OCS (dari instalasi sistem hingga penerbitan prosiding), tetapi lebih menekankan pada aspek manajemen konten informasi penyelenggaraan konferensi secara umum dan urgensinya dalam pengembangan kegiatan $e$ conference dan penerbitan e-proceeding secara online.

\section{METODOLOGI PENELITIAN}

Kajian ini bersifat deskriptif dengan pendekatan kualitatif yang sumber datanya berasal dari studi literatur dan praktik. Studi literatur digunakan untuk mencari teori atau pendapat yang relevan dengan pokok bahasan. Studi literatur mengacu pada informasi yang terkait dengan kegiatan konferensi, publikasi hasil konferensi, dan OCS. Berdasarkan hasil penelusuran di internet diketahui masih sangat sedikit literatur ilmiah yang membahas tentang e-conference dengan OCS sehingga informasi di situs OCS (https://pkp.sfu.ca/ocs/) menjadi dasar bahan kajian ini. Kemudian, untuk mengetahui jumlah prosiding yang terbit di Indonesia, penulis mengambil sampel prosiding ber-ISSN yang ada di database ISSN

PDII-LIPI

(http://issn.pdii.lipi.go.id/). Pendekatan praktik dilakukan dengan cara simulasi instal, mengelola konten, dan penerbitan makalah call for paper melalui sistem OCS offline. Simulasi pengelolaan e-conference ini menggunakan server lokal XAMPP Control Panel versi v3.2.1 (Gambar 1) dan OCS versi 2.3.5.0, dengan URL database di http://localhost/ocslatihan (Gambar 2).

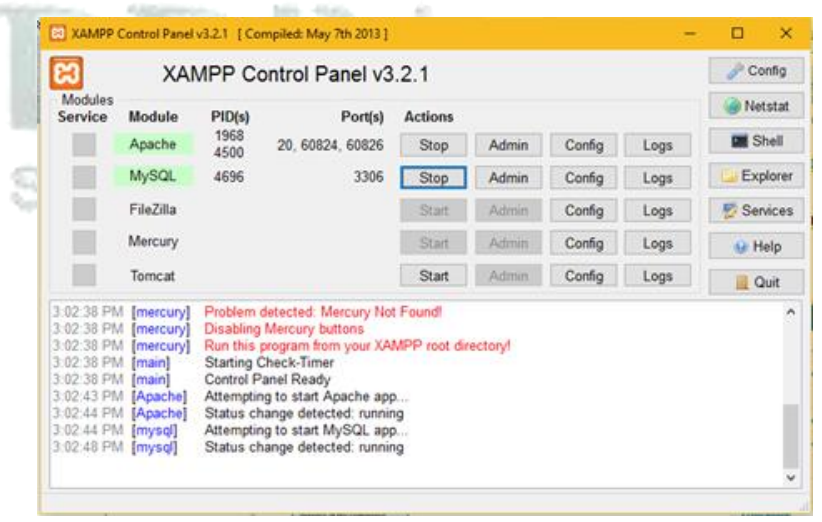

Gambar 1. XAMPP Control Panel versi v3.2.1

Ketika simulasi, penulis mencoba untuk mendisain situs dan mengelola 
konten OCS agar lebih menarik, sehingga hasilnya dapat dilihat pada Gambar 2.

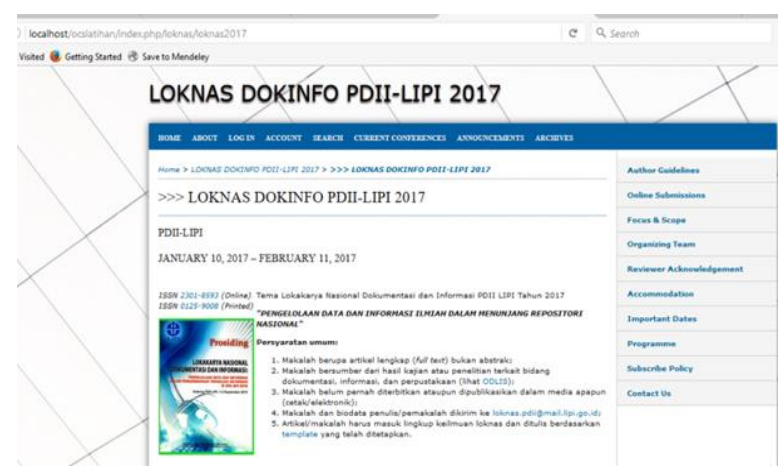

Gambar 2. Tampilan Simulasi OCS di Server Offline (sumber: http://localhost/ocslatihan)

Kemudian, hasil studi literatur dan praktek ini dijabarkan dalam hasil dan pembahasan kajian ini. Hasil dan pembahasan ini menjadi dasar kesimpulan kajian ini.

\section{HASIL DAN PEMBAHASAN}

\section{a. Ketentuan Kegiatan Konferensi dan Publikasi Hasil Kegiatannya}

Sebelum membahas tentang upaya pengembangan dan teknis pengelolaan $e$ conference terlebih dahulu dijelaskan tentang "konferensi" dan "hasil dari kegiatan konferensi". Reitz (2014) mendefinisikan konferensi (conference) sebagai pertemuan formal sekelompok individu atau perwakilan dari beberapa badan untuk tujuan membahas topik dan/atau membuat keputusan bersama atas isu-isu yang sedang berkembang. Kegiatan pertemuan sejenis konferensi, antara lain workshop, symposium, exhibition, exposition, festival, athletic contest, scientific expedition, dan sebagainya. Besar kecilnya kegiatan konferensi sangat tergantung pada lingkup skala penyelenggaraannya, apakah konferensi tingkat internasional ataupun tingkat nasional. Berikut ini ada beberapa kriteria dari konferensi, seminar, simposium, atau lokakarya tingkat internasional dan tingkat nasional (Tabel $1)$.

Tabel 1. Kriteria Konferensi Tingkat Internasional dan Nasional

\begin{tabular}{|c|c|}
\hline Konferensi Tingkat Internasional & Konferensi Tingkat Nasional \\
\hline 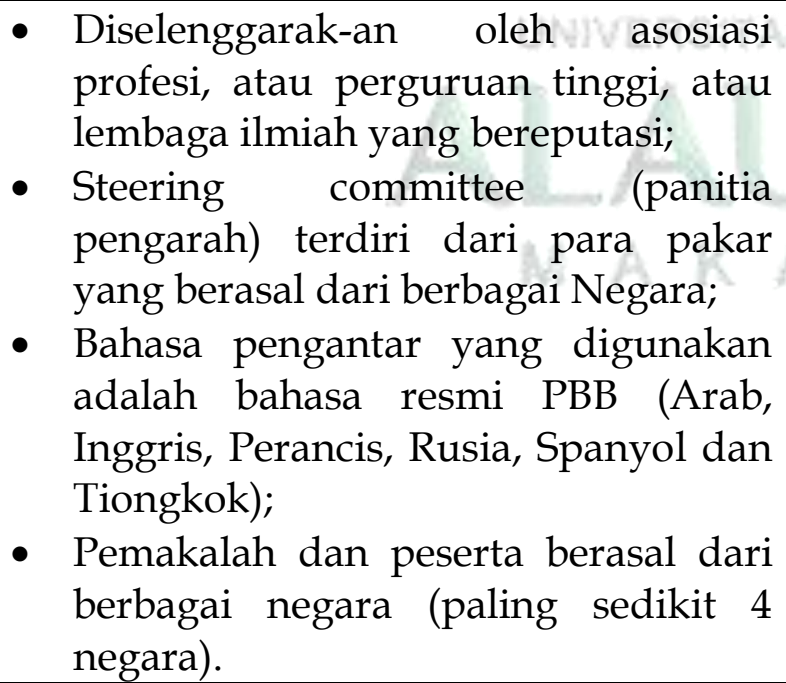 & $\begin{array}{l}\text { - Diselenggarak-an oleh asosiasi profesi, } \\
\text { atau perguruan tinggi, atau lembaga } \\
\text { ilmiah yang bereputasi; } \\
\text { - Steering committee (panitia pengarah) } \\
\text { yang terdiri dari para pakar; } \\
\text { - Bahasa pengantar yang digunakan adalah } \\
\text { bahasa Indonesia; } \\
\text { - Pemakalah dan peserta berasal dari } \\
\text { berbagai perguruan tinggi/lemba-ga } \\
\text { ilmiah lingkup nasional }\end{array}$ \\
\hline
\end{tabular}

Sumber: Dirjen-DIKTI (2014)

Adapun hasil (output) dari kegiatan konferensi, baik tingkat internasional maupun nasional, adalah makalah/prosiding. Rusdi dan Thoha (2012) menjelaskan ada beberapa ketentuan yang terkait dengan publikasi 
ilmiah berupa makalah seminar/prosiding: (1) penulis tunggal/kolektif bebas; (2) sumber data merupakan hasil kajian/penelitian; (3) struktur penulisan sebagaimana sistematika laporan penelitian; (4) jumlah halaman antara 10-20 halaman; (5) format kertas ukuran kuarto/A4; (6) konsumen/pembaca dari kalngan peneliti/pakar; dan (7) penerbit adalah penyelenggara seminar.

Makalah yang dimaksud di sini adalah makalah lengkap call for paper yang sudah dipresentasikan, di edit, di review, dilayout, dan disusun dalam format terjilid hingga menjadi satu-kesatuan publikasi utuh tetapi belum memiliki nomer unik terbitan (ISSN/ISBN). Makalah lengkap merupakan tulisan ilmiah yang disusun berdasarkan analisis dan sintesis data hasil litbang dan/atau tinjauan, ulasan/review, kajian, dan pemikiran sistematis yang belum pernah ditulis dan dipublikasikan oleh orang lain serta topik yang dibahas berupa topik baru yang menambah informasi baru-dan/atau memperkuat temuan/topik sebelumnya (LIPI, 2012). Sementara itu, prosiding adalah kumpulan KTI yang diterbitkan sebagai hasil suatu pertemuan ilmiah dan telah melalui proses penyuntingan (LIPI,
2014). Menurut Reitz (2014), prosiding merupakan catatan yang dipublikasikan pada acara konferensi, kongres, simposium, atau pertemuan ilmiah lainnya yang disponsori oleh suatu masyarakat atau asosiasi. Biasanya materi prosiding disajikan dalam bentuk abstrak atau laporan ringkas dari makalah yang disajikan kepada para peserta. Informasi prosiding berupa kajian hasil pertemuan atau konferensi yang diselenggarakan secara teratur, baik dalam materi yang disampaikan pada saat pelakasanaan seminar (teknis) maupun proses diskusi dalam suatu konferensi (Magrill, 1984). Suatu publikasi dikatakan prosiding apabila memenuhi persyaratan administratif: (a) mencantumkan tema dan institusi pelaksana seminar; (b) memiliki paling sedikit dua orang editor dan melalui proses editing; dan (c) memiliki ISSN jika seminarnya berkala atau ISBN jika seminarnya tidak berkala, kecuali seminar internasional tanpa perlu memiliki ISBN (LIPI Press, 2014). Kritesia prosiding pun berbeda sesuai dengan lingkup kegiatan konferensi (Tabel 1). Berikut ini ada beberapa kriteria dari prosiding internasional dan prosiding nasional yäng diterbitkan berupa buku ilmiah (Tabel 2).

Tabel 2. Kriteria Prosiding Internasional dan Nasional

\begin{tabular}{|c|c|}
\hline Prosiding Internasional & Prosiding Nasional \\
\hline $\begin{array}{l}\text { - Bahasa yang digunakan adalah bahasa } \\
\text { resmi PBB (Inggris, Perancis, Spanyol, } \\
\text { Arab, Rusia, atau Mandarin). KTI yang } \\
\text { ditulis selain dalam bahasa Inggris } \\
\text { harus melampirkan abstrak dalam } \\
\text { bahasa Inggris atau bahasa Indonesia; } \\
\text { - Penulis makalah yang dimuat dalam } \\
\text { prosiding paling sedikit berasal dari }\end{array}$ & $\begin{array}{l}\text { - Memuat makalah lengkap; } \\
\text { - Ditulis dalam Bahasa Indonesia; } \\
\text { - Penulis paling sedikit berasal dari } 4 \\
\text { (empat) institusi; } \\
\text { - Editor sesuai dengan bidang ilmunya; } \\
\text { - Memiliki ISBN; } \\
\text { - Diterbitkan oleh lembaga ilmiah yang } \\
\text { bereputasi, yaitu organisasi profesi, }\end{array}$ \\
\hline
\end{tabular}


tiga negara dan sekurang-kurangnya $30 \%$ tulisan berasal dari dua negara lain;

- Prosiding telah melalui proses penyuntingan (editing);

- Penyunting/editor paling sedikit berasal dari dua Negara (LIPI, 2014). Apabila prosiding diterbitkan dalam bentuk buku ilmiah, selain kriteria di atas harus memenuhi kriteria: (a) editor berasal dari berbagai negara sesuai dengan bidang ilmunya; (b) penulis paling sedikit berasal dari 4 (empat) negara; dan (c) memiliki ISBN.

Sumber: LIPI (2014) dan Dirjen-DIKTI (2014)

\section{b. Jumlah Prosiding Ber-ISSN yang Terbit di Indonesia}

Berdasarkan hasil penelusuran di database ISSN PDII-LIPI (http://issn.pdii.lipi.go.id/) diketahui bahwa jumlah publikasi prosiding yang terbit di Indonesia hanya terdapat 997 prosiding yang ber-ISSN (Tabel 3 dan Gambar 3), dan dari jumlah tersebut hanya diketahui 63 prosiding yang diterbitkan secara online (Tabel 4).

Tabel 3. Data Prosiding Ber-ISSN Sumber: http://issn.pdii.lipi.go.id/ perguruan tinggi, lembaga penelitian

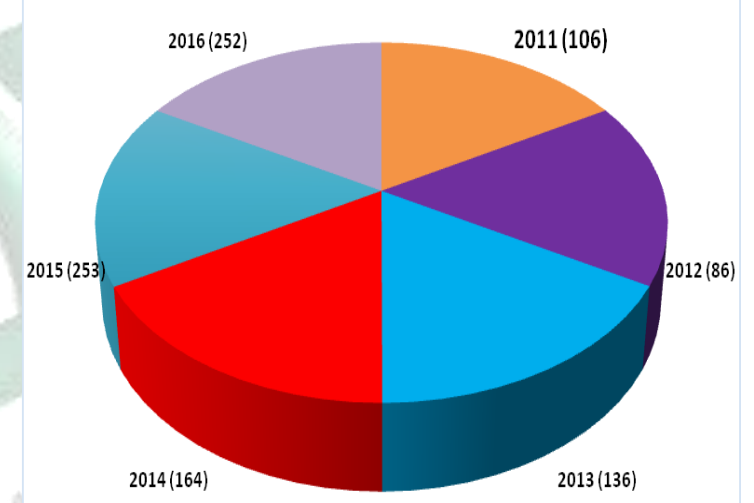

Gambar 3. Data prosiding ber-ISSN Sumber: http://issn.pdii.lipi.go.id/

\begin{tabular}{|c|c|}
\hline Tahun ISSN & Jumlah \\
\hline 2011 & 106 \\
\hline 2012 & 86 \\
\hline 2013 & 136 \\
\hline 2014 & 164 \\
\hline 2015 & 253 \\
\hline 2016 & 252 \\
\hline Jumlah & $\mathbf{9 9 7}$ \\
\hline
\end{tabular}


Tabel 4. Data E-Proceeding Ber-ISSN

\begin{tabular}{|c|c|c|c|c|}
\hline No & Publikasi & $\begin{array}{l}\text { Register } \\
\text { ISSN }\end{array}$ & ISSN & $\begin{array}{l}\text { Sistem } \\
\text { Aplikasi }\end{array}$ \\
\hline 1 & $\begin{array}{l}\text { Proceedings of The ACIE (Annual } \\
\text { Conference on Islamic Education) (Fak-ultas } \\
\text { Ilmu Tarbiyah dan Keguruan UIN Sunan } \\
\text { Kalijaga) }\end{array}$ & $08 / 12 / 16$ & $2548-5792$ & OCS \\
\hline 2 & $\begin{array}{l}\text { Proceedings ACIECE (Annual Conference on } \\
\text { Islamic Early Childhood } \\
\text { Education) (Program Studi Pendidikan Guru } \\
\text { Raudlatul Athfal Fakultas Ilmu Tarbiyah dan } \\
\text { Keguruan UIN Sunan Kalijaga) }\end{array}$ & $28 / 11 / 16$ & $2548-4516$ & OCS \\
\hline 3 & $\begin{array}{l}\text { Prosiding Seminar Lignoselulosa (Pusat } \\
\text { Penelitian Biomaterial LIPI) }\end{array}$ & $30 / 12 / 16$ & $2548-8767$ & OJS \\
\hline 4 & $\begin{array}{l}\text { Prosiding SNFA (Seminar Nasional Fisika } \\
\text { dan Aplikasinya) (Universitas Sebelas Maret } \\
\text { Surakarta) }\end{array}$ & $01 / 11 / 16$ & $2548-8325$ & OJS \\
\hline 5 & $\begin{array}{l}\text { Proceeding SNIRT (Seminar Nasional } \\
\text { Inovasi dan Rekayasa Teknologi) (Fakultas } \\
\text { Teknik Universitas } 17 \text { Agustus Cirebon) }\end{array}$ & $13 / 12 / 16$ & $2548-8058$ & OJS \\
\hline 6 & $\begin{array}{l}\text { Proceedings of the ICECRS (International } \\
\text { Consortium of Education and Culture } \\
\text { Research Studies) }\end{array}$ & $02 / 12 / 16$ & $2548-6160$ & OJS \\
\hline 7 & $\begin{array}{l}\text { Proceeding Seminar Nasional Ilmu } \\
\text { Komputer (SEMINASIK) (Fakultas Ilmu } \\
\text { Komputer (FIKOM)) }\end{array}$ & $03 / 11 / 16$ & $2548-1460$ & OJS \\
\hline 8 & $\begin{array}{l}\text { JGEET (Journal of Geoscience, Engineering, } \\
\text { Environment and Technology) (Program } \\
\text { Studi Teknik Geologi, Fakultas Teknik, } \\
\text { Universitas Islam Riau) }\end{array}$ & $02 / 09 / 16$ & $2541-5794$ & OJS \\
\hline 9 & $\begin{array}{l}\text { Prosiding Sendimas (Seminar Nasional } \\
\text { Pengabdian Masyarakat) (LPPM Universitas } \\
\text { Kristen Duta Wacana Yogyakarta) }\end{array}$ & $06 / 10 / 16$ & 2541-3805 & OJS \\
\hline 10 & $\begin{array}{l}\text { Proceeding of Chemistry } \\
\text { Conference (Program Studi Kimia, Fakultas } \\
\text { Matematika dan Ilmu Pengetahuan Alam, } \\
\text { Universitas Sebelas Maret) }\end{array}$ & $28 / 07 / 16$ & $2541-108 X$ & OJS \\
\hline 11 & $\begin{array}{l}\text { Prosiding SAKTI (Seminar Ilmu Komputer } \\
\text { dan Teknologi Informasi) (Fakultas Ilmu } \\
\text { Komputer dan Teknologi Informasi (FKTI) } \\
\text { Universitas Mulawarman) }\end{array}$ & $30 / 08 / 16$ & $2540-7902$ & OJS \\
\hline 12 & $\begin{array}{l}\text { Proceeding SENATIK (Seminar Nasional } \\
\text { Teknologi Informasi dan } \\
\text { Kedirgantaraan) (Sekolah Tinggi Teknologi } \\
\text { Adisucipto Yogyakarta) }\end{array}$ & $16 / 06 / 16$ & $2528-1666$ & OJS \\
\hline
\end{tabular}




\begin{tabular}{|c|c|c|c|c|}
\hline 13 & $\begin{array}{l}\text { Prosiding Senatkom (Lembaga Penelitian } \\
\text { dan Pengabdian Masyarakat, Universitas } \\
\text { Putra Indonesia YPTK Padang) }\end{array}$ & 05/01/16 & 2527-9491 & OJS \\
\hline 14 & $\begin{array}{l}\text { Prosiding SNHP3M (Seminar Nasional Hasil } \\
\text { Penerapan Penelitian Dan Pengabdian Pada } \\
\text { Masyarakat) (Lembaga Pengabdian Kepada } \\
\text { Masyarakat Dan Ventura (LPKMV), } \\
\text { Universitas Tarumanagara, Jakarta) }\end{array}$ & $03 / 05 / 16$ & $2527-5658$ & OJS \\
\hline 15 & $\begin{array}{l}\text { Proceedings of The ILCAN Conference Series } \\
\text { on Life Cycle Assessment (Indonesian Life } \\
\text { Cycle Assessment Network (ILCAN)) }\end{array}$ & $29 / 12 / 16$ & $2548-8155$ & website \\
\hline 16 & $\begin{array}{l}\text { Proceeding ICMSC (International Conference } \\
\text { on Mathematics, Science, and Computer } \\
\text { Science) (Fakultas MIPA Universitas } \\
\text { Mulawarman Samarinda) }\end{array}$ & $11 / 12 / 16$ & $2548-7469$ & website \\
\hline 17 & $\begin{array}{l}\text { Prosiding Seminar Nasional Fakultas Ilmu } \\
\text { Sosial dan Ilmu Politik Universitas } \\
\text { Terbuka (Fakultas Ilmu Sosial dan Ilmu } \\
\text { Politik Universitas Terbuka) }\end{array}$ & $07 / 12 / 16$ & $2548-6799$ & website \\
\hline 18 & $\begin{array}{l}\text { Prosiding Seminar Nasional MASTER } \\
\text { (Maritim, Sains, dan Teknologi } \\
\text { Terapan) (Politeknik Perkapalan Negeri } \\
\text { Surabaya) }\end{array}$ & $15 / 11 / 16$ & $2548-6527$ & website \\
\hline 19 & $\begin{array}{l}\text { ICONIC (International Conference of } \\
\text { Integrated Intellectual Community) } \\
\text { Proceeding (PPI Jerman (Vereinigung } \\
\text { Indonesischer Studenten e.V)) }\end{array}$ & $07 / 12 / 16$ & $2548-6217$ & website \\
\hline 20 & $\begin{array}{l}\text { Prosiding Seminar Nasional Perteta Sumbar } \\
\text { (Perhimpunan Teknik } \\
\text { Pertanian) (Perhimpunan Teknik Pertanian } \\
\text { Cabang Sumbar) }\end{array}$ & $08 / 11 / 16$ & $2548-5040$ & website \\
\hline 21 & $\begin{array}{l}\text { Proceedings AISTEEL (Annual International } \\
\text { Seminar on Transformative Education and } \\
\text { Educational Leadership) (Pascasarjana } \\
\text { Universitas Negeri Medan) }\end{array}$ & $24 / 11 / 16$ & $2548-4613$ & website \\
\hline 22 & $\begin{array}{l}\text { Prosiding SNITI (Seminar Nasional Inovasi } \\
\text { dan Teknologi Informasi) (Forum IHAN- } \\
\text { BATAK) }\end{array}$ & $27 / 11 / 16$ & $2548-4540$ & website \\
\hline 23 & $\begin{array}{l}\text { Proceeding of ICoSITeR (International } \\
\text { Conference on Science, Infrastructure } \\
\text { Technology and Regional } \\
\text { Development) (Institut Teknologi Sumatera) }\end{array}$ & $22 / 09 / 16$ & $2548-3927$ & website \\
\hline 24 & $\begin{array}{l}\text { Proceeding Icitech Conference (Teknik } \\
\text { Informatika FTI Universitas Kristen Sayta } \\
\text { Wacana) }\end{array}$ & $18 / 10 / 16$ & 2548-1665 & website \\
\hline 25 & $\begin{array}{l}\text { Proceeding of National Conference on ASBIS } \\
\text { (Applied Science, Business and Information }\end{array}$ & $24 / 10 / 16$ & $2541-6022$ & website \\
\hline
\end{tabular}




\begin{tabular}{|c|c|c|c|c|}
\hline & System) (Politeknik Negeri Banjarmasin) & & & \\
\hline 26 & $\begin{array}{l}\text { Prosiding SNRT (Seminar Nasional Riset } \\
\text { Terapan) (Politeknik Negeri Banjarmasin) }\end{array}$ & $01 / 11 / 16$ & $2541-5670$ & website \\
\hline 27 & $\begin{array}{l}\text { Prosiding Seminar Nasional SNSTL (Sains } \\
\text { dan Teknologi Lingkungan) (Jurusan Teknik } \\
\text { Lingkungan, Fakultas Teknik, Universitas } \\
\text { Andalas) }\end{array}$ & $24 / 08 / 16$ & $2541-3880$ & website \\
\hline 28 & $\begin{array}{l}\text { Proceedings International Conference on } \\
\text { Language, Literary and Cultural } \\
\text { Studies (Fakultas Ilmu Budaya Universitas } \\
\text { Brawijaya) }\end{array}$ & $20 / 10 / 16$ & 2541-3821 & website \\
\hline 29 & $\begin{array}{l}\text { Proceedings ICONIES (International } \\
\text { Conference on Islamic Economics and } \\
\text { Business) (Fakultas Ekonomi, UIN Maulana } \\
\text { Malik Ibrahim Malang) }\end{array}$ & $18 / 10 / 16$ & $2541-3333$ & website \\
\hline 30 & $\begin{array}{l}\text { Prosiding Semnasvoktek (Seminar Nasional } \\
\text { Vokasi dan Teknologi) (Fakultas Teknik dan } \\
\text { Kejuruan, Universitas Pendidikan Ganesha } \\
\text { Singaraja) }\end{array}$ & $04 / 10 / 16$ & $2541-3058$ & website \\
\hline 31 & $\begin{array}{l}\text { Prosiding Seminar Nasional } \\
\text { Celscitech (Lembaga Penelitian dan } \\
\text { Pengabdian Masyarakat, Universitas } \\
\text { Muhammadiyah Riau) }\end{array}$ & $18 / 09 / 16$ & $2541-3023$ & website \\
\hline 32 & $\begin{array}{l}\text { Prosiding Conference on Management and } \\
\text { Behavioral Studies (Program Studi S1 } \\
\text { Manajemen Bisnis, Fakultas Ekonomi } \\
\text { Universitas Tarumanagara Jakarta) }\end{array}$ & $18 / 09 / 16$ & $2541-285 X$ & website \\
\hline 33 & $\begin{array}{l}\text { Prosiding SNTI (Seminar Nasional Teknologi } \\
\text { Informasi) (Fakultas Teknologi Informasi, } \\
\text { Universitas Tarumanagara Jakarta) }\end{array}$ & $04 / 10 / 16$ & $2541-240 X$ & website \\
\hline 34 & $\begin{array}{l}\text { Proceedings ICSBE (International Conference } \\
\text { on Sustainable Built Environment) (Fakultas } \\
\text { Teknik Sipil dan Perencanaan, Universitas } \\
\text { Islam Indonesia) }\end{array}$ & $25 / 08 / 16$ & $2541-223 X$ & website \\
\hline 35 & $\begin{array}{l}\text { The International proceeding of teaching and } \\
\text { linguistics (Jurusan Pendidikan Bahasa } \\
\text { Inggris, Fakultas Keguruan dan Ilmu } \\
\text { Pendidikan, Universitas HKBP Nommensen } \\
\text { Medan) }\end{array}$ & $20 / 09 / 16$ & $2541-1543$ & website \\
\hline 36 & $\begin{array}{l}\text { Proceedings Book: Rakernas dan PIT Ikatan } \\
\text { Apoteker Indonesia (Ikatan Apoteker } \\
\text { Indonesia) }\end{array}$ & $20 / 09 / 16$ & 2541-0474 & website \\
\hline 37 & $\begin{array}{l}\text { Prosiding Fokus Keamanan Informasii: } \\
\text { Information Security Focus Proceeding (ID- } \\
\text { SIRTII/CC Kemenkominfo) }\end{array}$ & $08 / 09 / 16$ & $2540-9743$ & website \\
\hline 38 & Prosiding SNAMK (Seminar Nasional & 03/09/16 & $2540-914 X$ & website \\
\hline
\end{tabular}




\begin{tabular}{|c|c|c|c|c|}
\hline & $\begin{array}{l}\text { Akuntansi Manajemen dan } \\
\text { Keuangan) (Jurusan Akuntansi Politeknik } \\
\text { Negeri Malang) }\end{array}$ & & & \\
\hline 39 & $\begin{array}{l}\text { Proceedings International Seminar Language } \\
\text { Maintenance and Shift (LAMAS) (Prodi } \\
\text { Magister Linguistik Program Pascasarjana } \\
\text { Universitas Diponegoro) }\end{array}$ & $24 / 08 / 16$ & $2540-8755$ & website \\
\hline 40 & $\begin{array}{l}\text { Prosiding Seminar Nasional } \\
\text { Cendekiawan (Lembaga Penelitian, } \\
\text { Universitas Trisakti Jakarta) }\end{array}$ & $26 / 08 / 16$ & $2540-7589$ & website \\
\hline 41 & $\begin{array}{l}\text { Proceedings ICEEBF (International } \\
\text { Conference on Education for Economics, } \\
\text { Business, and Finance) (Fakultas Ekonomi } \\
\text { Universitas Negeri Malang) }\end{array}$ & $15 / 08 / 16$ & $2540-7481$ & website \\
\hline 42 & $\begin{array}{l}\text { The International Youth Symposium on } \\
\text { Creative Agriculture (International } \\
\text { Association of Student in Agricultural and } \\
\text { Related Sciences Local Committee IPB (IAAS } \\
\text { LC IPB)) }\end{array}$ & $08 / 08 / 16$ & $2528-7451$ & website \\
\hline 43 & $\begin{array}{l}\text { ICEBESS (International Conference on Ethics } \\
\text { of Business, Economics, and Social Science) } \\
\text { Proceeding (Fakultas Ekonomi, Universitas } \\
\text { Negeri Yogyakarta) }\end{array}$ & $19 / 08 / 16$ & $2528-617 X$ & website \\
\hline 44 & $\begin{array}{l}\text { Proceedings of ICBEST (International } \\
\text { Conference on Business, Economics, Socio- } \\
\text { culture, and Tourism (Fakultas Ekonomi, } \\
\text { Universitas Semarang) }\end{array}$ & $15 / 08 / 16$ & $2528-5815$ & website \\
\hline 45 & $\begin{array}{l}\text { Prosiding Symbion (Symposium on Biology } \\
\text { Education) (Program Studi Pendidikan } \\
\text { Biologi, FKIP, Universitas Ahmad Dahlan } \\
\text { Yogyakarta) }\end{array}$ & $12 / 08 / 16$ & $2528-5726$ & website \\
\hline 46 & $\begin{array}{l}\text { UI Proceedings on Social Science and } \\
\text { Humanities (Direktorat Riset dan } \\
\text { Pengabdian Masyarakat, Universitas } \\
\text { Indonesia) }\end{array}$ & $08 / 08 / 16$ & $2528-4150$ & website \\
\hline 47 & $\begin{array}{l}\text { UI Proceedings on Science and } \\
\text { Technology (Direktorat Riset dan } \\
\text { Pengabdian Masyarakat, Universitas } \\
\text { Indonesia) }\end{array}$ & $08 / 08 / 16$ & $2528-4134$ & website \\
\hline 48 & $\begin{array}{l}\text { UI Proceedings on Health and } \\
\text { Medicine (Direktorat Riset dan Pengabdian } \\
\text { Masyarakat, Universitas Indonesia) }\end{array}$ & $08 / 08 / 16$ & $2528-4126$ & website \\
\hline 49 & $\begin{array}{l}\text { Prosiding Seminar Nasional Matematika, } \\
\text { Sains, dan Teknologi (Fakultas Matematika } \\
\text { dan Ilmu Pengetahuan Alam (FMIPA), } \\
\text { Universitas Terbuka) }\end{array}$ & $21 / 07 / 16$ & $2528-3081$ & website \\
\hline 50 & Prosiding Seminar Nasional FISIP & $12 / 07 / 16$ & $2528-1844$ & website \\
\hline
\end{tabular}




\begin{tabular}{|c|c|c|c|c|}
\hline & $\begin{array}{l}\text { UT (Fakultas Ilmu Sosial Dan Ilmu Politik, } \\
\text { Universitas Terbuka) }\end{array}$ & & & \\
\hline 51 & $\begin{array}{l}\text { Prosiding Temu Ilmiah Nasional } \\
\text { Guru (Fakultas Keguruan dan Ilmu } \\
\text { Pendidikan (FKIP), Universitas Terbuka) }\end{array}$ & $30 / 06 / 16$ & $2528-1593$ & website \\
\hline 52 & $\begin{array}{l}\text { Prosiding Seminar Nasional Pendidikan } \\
\text { Pancasila dan Kewarganegaraan (Program } \\
\text { Studi PPKn, Fakultas Keguruan Dan Ilmu } \\
\text { Pendidikan (FKIP) Universitas } \\
\text { Muhammadiyah Ponorogo) }\end{array}$ & $14 / 06 / 16$ & 2527-9971 & website \\
\hline 53 & $\begin{array}{l}\text { Proceeding ISE (International Seminar on } \\
\text { Education) (Fakultas Keguruan Dan Ilmu } \\
\text { Pendidikan (FKIP), Universitas } \\
\text { Muhammadiyah Ponorogo) }\end{array}$ & $14 / 06 / 16$ & 2527-9335 & website \\
\hline 54 & $\begin{array}{l}\text { Proceedings International Seminar Faculty of } \\
\text { Education (FoE) (Fakultas Ilmu Pendidikan, } \\
\text { Institut Keguruan dan Ilmu Pendidikan } \\
\text { (IKIP) PGRI Madiun) }\end{array}$ & $19 / 05 / 16$ & $2527-6824$ & website \\
\hline 55 & $\begin{array}{l}\text { Prosiding SENTRA (Seminar Teknologi dan } \\
\text { Rekayasa) (Fakultas Teknik, Universitas } \\
\text { Muhammadiyah Malang) }\end{array}$ & $18 / 05 / 16$ & $2527-6050$ & website \\
\hline 56 & $\begin{array}{l}\text { Semnas Ristek (Seminar Nasional Riset dan } \\
\text { Inovasi Teknologi) (Pusat Kajian dan Inovasi } \\
\text { Teknologi (Sakaintek), Universitas } \\
\text { Indraprasta PGRI Jakarta) }\end{array}$ & $19 / 05 / 16$ & $2527-5941$ & website \\
\hline 57 & $\begin{array}{l}\text { PharmaHealth (Universitas Muhammadiyah } \\
\text { Banjarmasin) }\end{array}$ & $04 / 05 / 16$ & $2527-5593$ & website \\
\hline 58 & $\begin{array}{l}\text { Prosiding KNASTIK (Konferensi Nasional } \\
\text { Teknologi Informasi dan } \\
\text { Komunikasi) (Fakultas Teknologi Informasi } \\
\text { Universitas Kristen Duta Wacana } \\
\text { Yogyakarta) }\end{array}$ & $28 / 03 / 16$ & $2503-4502$ & website \\
\hline 59 & $\begin{array}{l}\text { Proceeding of The First International } \\
\text { Seminar on Teacher Education (Fakultas } \\
\text { Tarbiyah dan Keguruan UIN Sultan Syarif } \\
\text { Kasim Riau) }\end{array}$ & $21 / 03 / 16$ & 2503-3662 & website \\
\hline 60 & $\begin{array}{l}\text { Prosiding Seminar Nasional FISIP } \\
\text { UMPO (Fakultas Ilmu Sosial dan Ilmu } \\
\text { Politik, Universitas Muhammadiyah } \\
\text { Ponororogo) }\end{array}$ & $16 / 03 / 16$ & $2503-278 X$ & website \\
\hline 61 & $\begin{array}{l}\text { Proceeding Unima IAPA International } \\
\text { Seminar and Annual Conference (Indonesian } \\
\text { Association for Public Administration) }\end{array}$ & $15 / 03 / 16$ & $2503-2763$ & website \\
\hline 62 & $\begin{array}{l}\text { Prosiding Seminar Nasional } \\
\text { Technopreneurship dan Alih }\end{array}$ & $18 / 02 / 16$ & $2502-6607$ & website \\
\hline
\end{tabular}




\begin{tabular}{|c|l|c|c|c|} 
& $\begin{array}{l}\text { Teknologi (Pusat Inovasi, Lembaga Ilmu } \\
\text { Pengetahuan Indonesia) }\end{array}$ & & \\
\hline 63 & $\begin{array}{l}\text { Proceedings of ICOTIC (International } \\
\text { Conference on Transformation in } \\
\text { Communications) (Program Studi Ilmu } \\
\text { Komunikasi, Universitas Telkom Bandung) }\end{array}$ & $13 / 01 / 16$ & $2502-3500$ & website \\
\hline
\end{tabular}

Sumber: http://issn.pdii.lipi.go.id/

Berdasarkan Tabel. 4 diketahui ada 2 institusi yang menerbitkan prosiding online dengan aplikasi OCS, 13 institusi menggunakan aplikasi OJS, dan 49 institusi menggunakan website sendiri. Hal tersebut dapat dilihat pada:

1) Proceedings of The ACIE (Annual Conference on Islamic Education Fakultas Ilmu Tarbiyah dan Keguruan UIN Sunan Kalijaga), akses di: http:/ / ejournal.uin-

suka.ac.id/tarbiyah/conference/index .php/ACIE/acie1 (Gambar 4).

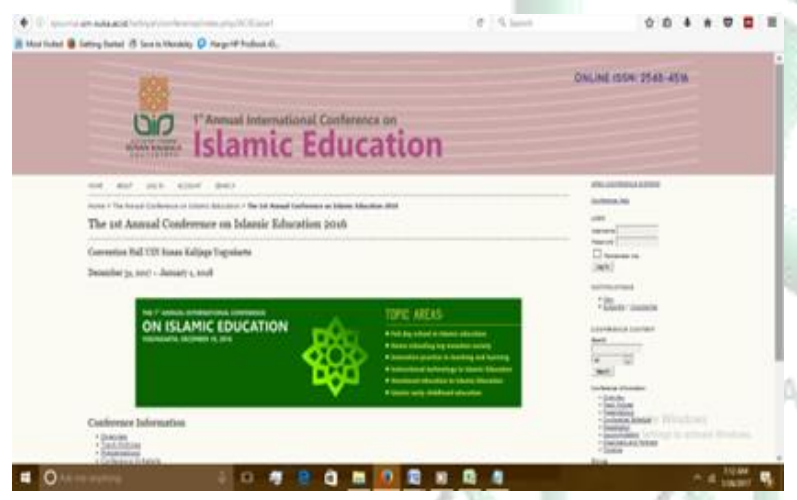

Gambar 4. Proceedings of The ACIE dengan OCS

2) Proceedings ACIECE (Annual Conference on Islamic Early Childhood Education Program Studi Pendidikan Guru Raudlatul Athfal Fakultas Ilmu Tarbiyah dan Keguruan UIN Sunan Kalijaga), akses di: http:/ / ejournal.uinsuka.ac.id/tarbiyah/conference/index .php/iciece/iciece1 (Gambar 5).

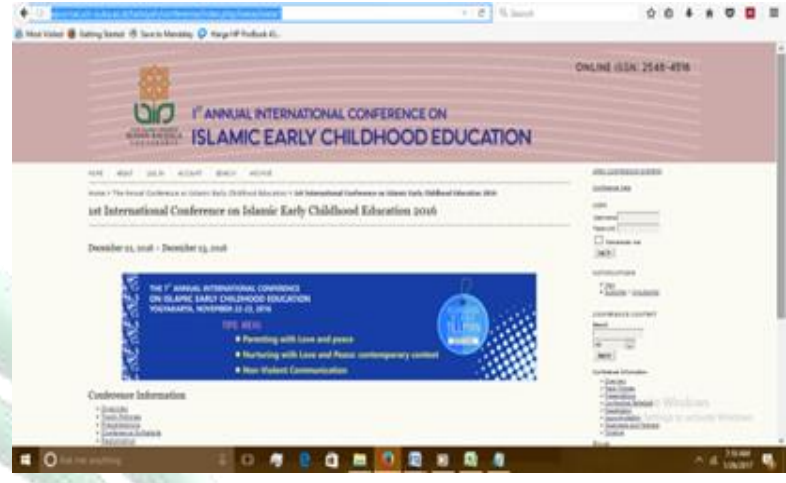

Gambar 5. Proceedings ACIECE dengan OCS

Adapun prosiding online yang dibangun dengan aplikasi OJS, dapat dilihat pada situs Proceedings of the ICECRS - International Consortium of Education and Culture Research Studies akses

http://ojs.umsida.ac.id/index.php/icecrs (Gambar 6) dan Prosiding SNHP3M (Seminar Nasional Hasil Penerapan Penelitian dan Pengabdian Pada Masyarakat, Lembaga Pengabdian Kepada Masyarakat Dan Ventura (LPKMV) - Universitas Tarumanagara Jakarta akses di http://lpkmvuntar.org/jurnal/index.php/snhp3m/ind ex (Gambar 7).

PROCEEDINGS OF THE ICECRS

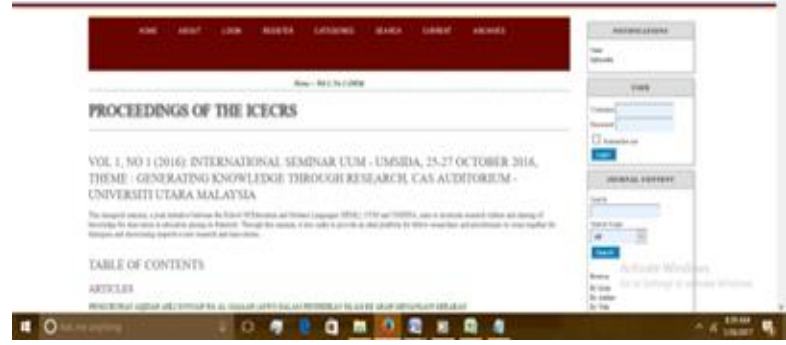

Gambar 6. Proceedings of the ICECRS dengan OJS 


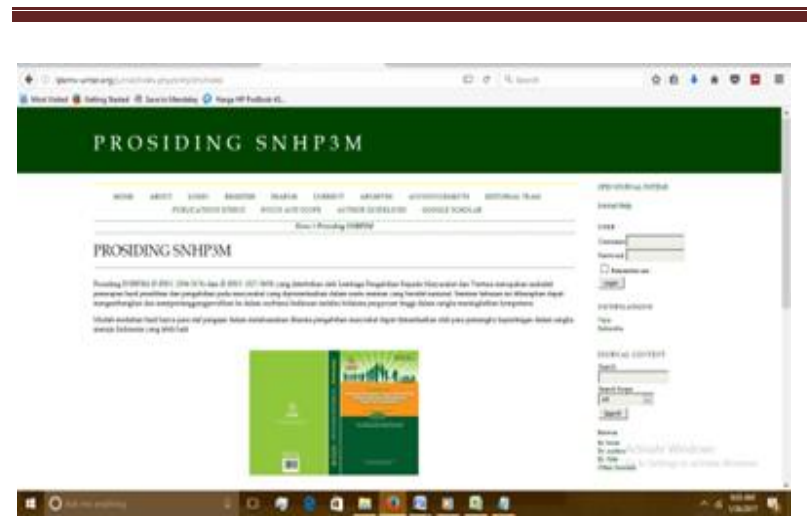

Gambar 7. Prosiding SNHP3M dengan OJS

Adapun prosiding online yang dibangun dengan wesbsite sendiri, dapat dilihat pada situs Proceedings of ICOTIC (International Conference on Transformation in Communications) (Program Studi Ilmu Komunikasi, Universitas Telkom Bandung) akses di https://openlibrary.telkomuniversity.ac.i d/home/epublication/id/63.html

(Gambar 8) dan Prosiding Seminar Nasional Technopreneurship dan Alih Teknologi (Pusat Inovasi, Lembaga Ilmu Pengetahuan Indonesia) akses di http://inovasi.lipi.go.id/tekno-altek/ (Gambar 9).

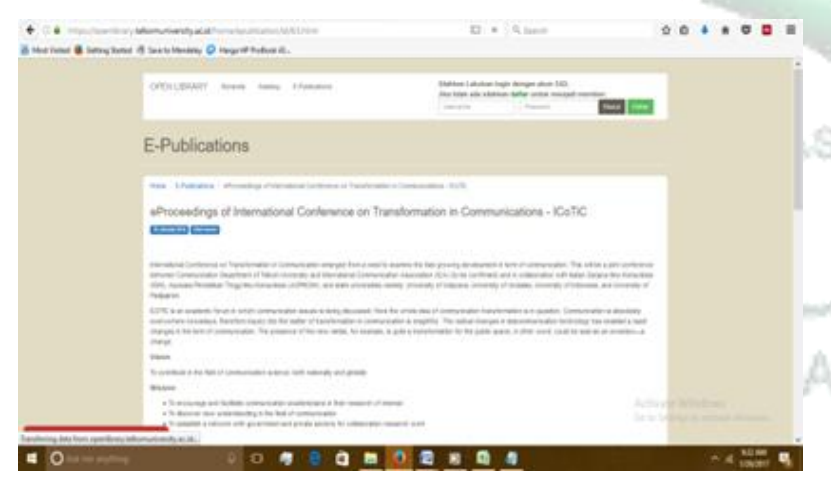

Gambar 8. Proceedings of ICOTIC dengan Website

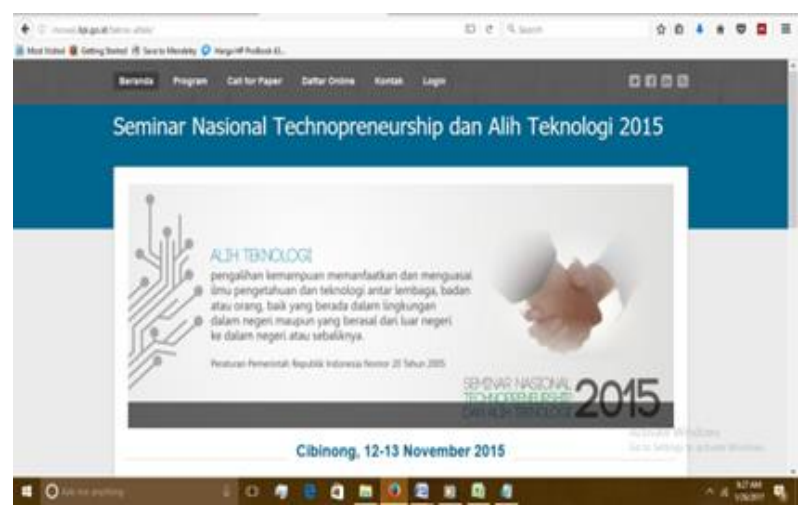

Gambar 9. Prosiding Seminar Nasional Technopreneurship dan Alih Teknologi dengan Website

Melihat jumlah terbitan e-proceeding yang masih sedikit dibanding e-journal perlu ada upaya keras dan komitmen dari pihak penyelenggara konferensi dan pemerintah untuk meningkatkan penerbitan e-proceeding sebagaimana yang telah diupayakan pada terbitan e-journal yakni melalui sistem akreditasi jurnal.

\section{c. Upaya Pengembangan E-Conference di Indonesia}

Sistem e-conference ini dikembangkan dalam rangka meningkatkan asksesibilitas masyarakat global terhadap isi informasi prosiding yang dihasilkan oleh suatu institusi/lembaga. Menjadi sia-sia jika prosiding yang dihasilkan hanya sebagai arsip dan koleksi lembaga serta hanya tersimpan di rak perpustakaan. Oleh karena itu, penyelenggaraan konferensi ini juga harus dikelola secara professional dengan bantuan teknologi computer dan internet, yaitu mengimplementasikannya dengan menggunakan program OCS untuk penyelenggaraan e-conference. Berikut ini ada beberapa alasan penting (urgent) bagi suatu institusi/lembaga untuk menyelenggarakan e-conference dengan OCS, yaitu: (1) meningkatkan jumlah partisipan kegiatan konferensi, baik perserta, pemakalah, maupun sponsor/promotor; (2) meningkatkan 
kuantitas dan kualitas makalah (call for paper), karena melalui promosi konferensi melalui online akan lebih menarik minat masyarakat untuk berkontribusi tulisan/makalah; (3) meningkatkan kualitas seleksi makalah call for paper dan penerbitan prosiding; (4) meningkatkan webometrik lembaga, karena publikasi ilmiah, seperti jurnal, prodisidng, buku, dan laporan penelitian yang dihasilkan lembaga, dapat menyumbang peningkatan webometrik lembaga; dan (5) meningkatkan reputasi lembaga sebagai scientific institution, karena melalui kegiatan konferensi akan memicu kerjasama dan koloborasi penelitian ilmiah secara global.

Untuk mewujudkan penyelenggaraan konferensi dengan sistem online ini, dibutuhkan beberapa upaya yang serius dari pemerintah dan penyelenggara konferensi. Upaya serius dari pemerintah tersebut berupa komitmen yang kuat untuk pengembangan e-conference di Indonesia. Komitmen tersebut mungkin dapat diterapkan sebagaimana pemerintah (Kemenristek-DIKTI dan LIPI) telah mewajibkan penerbitan e-journal ilmiah di Indonesia agar dapat terakreditasi dan bereputasi internasional. Terkait dengan upaya pengembangan $e$ journal di Indonesia, Lukman (2016) mengatakan ada beberapa upaya yang telah dilakukan oleh pemerintah. Di mana sejak tahun 2009, PDII-LIPI, Kemenristekditik, Ditlitabmas-Dikti, dan Pusbindiklat Peneliti-LIPI berupaya keras untuk mendorong penerbitan e-journal melalui berbagai kegiatan, antara lain: (1) penerjemahan dan adopsi Open Journal System/OJS di Indonesia sebagai aplikasi e-journal (tahun 2009); (2) pembuatan panduan OJS agar dapat diimplementasikan oleh pengelola jurnal (tahun 2010); (3) pelatihan OJS dasar untuk pengelolaan e-journal (tahun 20112012); (4) pelatihan manajemen e-journal (tahun 2012-2016); (5) penyediaan literatur e-journal berlangganan untuk menyediakan referensi primer dan mutakhir bagi penulis sehingga dapat menghasilkan naskah ilmiah yang berkualitas (tahun 2010-2016); (6) pelatihan Training of Trainer/TOT Penulisan Artikel Ilmiah untuk persiapan naskah yang akan di-submit ke jurnal nasional ataupun internasional (tahun 2009-2016); (7) penyusunan dan penetapan bersama pedoman akreditasi terbitan berkala ilmiah elektronik (DIKTI dan LIPI tahun 2012) dan ditetapkan Peraturan Dirjen DIKTI No.1 Tahun 2014 dan Peraturan Kepala LIPI No.3 Tahun 2014 tentang Pedoman Akreditasi Terbitan Berkala Ilmiah tanggal 1 September 2014; (8) workshop internasionalisasi jurnal dan pemberian insentif jurnal terindeks (tahun 2013-2014) untuk membina jurnal ilmiah Indonesia sehingga terindeks di lembaga pengindeks bereputasi dan memberikan apresiasi atas upaya jurnal yang sudah terindeks di pengindeks internasional bereputasi; (9) persiapan sistem informasi Akreditasi Jurnal Nasional secara elektronik/online melalui situs ARJUNA (http://arjuna.dikti.go.id) pada tahun 2012; (10) pelatihan pengajuan akreditasi jurnal dengan sistem ARJUNA secara daring (tahun 2012); (11) persiapan Tim Nasional Akreditasi Tebitan Berkala Ilmiah/TBI dan Penyiapan Tim Asesor Substansi dan Asesor Tatakelola Akreditasi TBI (tahun 2015); (12) pelatihan TOT dan penyamaan persepsi asesor akreditasi TBI (tahun 2015); (13) persiapan dan pemberian bantuan tata kelola jurnal elektronik sehingga ada peningkatan reputasi jurnal menjadi jurnal bereputasi internasional (tahun 2015); dan (14) proses re-evaluasi dan monitoring terbitan berkala ilmiah terakreditasi (kebijakan ini direncanakan dua tahun sekali bagi jurnal yang sudah terakreditasi sehingga terjaga 
mutunya dan akan dilaksanakan tahun 2017). Selain upaya tersebut, diperkuat dengan terbitnya Surat Edaran Kemenristek-DIKTI Nomor 193/E/SE/XII/2015 tentang Akreditasi Jurnal Ilmiah Secara Elektronik, yang menegaskan bahwa mulai tanggal 1 April 2016, Direktorat Jenderal Penguatan Riset dan Pengembangan Direktorat Pengelolaan Kekayaan Intelektual hanya menerima dan memproses usulan akreditasi jurnal (terbitan berkala) ilmiah nasional yang telah dikelola secara elektronik sehingga proses penilaian akan lebih mudah, cepat, akurat dan transparan. Hal-hal di atas tentunya berdampak langsung pada kewajiban bagi penerbit atau pengelola jurnal untuk segera menyiapkan dan menerbitan jurnal dalam versi daring/online agar terbitannya dapat terakreditasi. Berbagai upaya di atas dapat menjadi preferensi bagi pemerintah untuk meningkatkan penerbitan e-conference dalam bentuk $e$ proceeding di Indonesia.

Kemudian, upaya dari penyelenggara konferensi dalam penyelenggaraan $e$ conference antara lain dengan: berkomitmen untuk menyelanggarakan konferensi, seminar, dan pertemuan ilmiah sejenisnya dengan sistem online, dapat menggunakan aplikasi OCS atau sistem lain yang memenuhi kaidah-kaidah publikasi ilmiah; (2) $A$ bagi institusi/lembaga yang sudah menerapkan $e$-conference dan menerbitkan prosiding dengan sistem elektronik/online harus berbagi pengetahuan dan mensosialisasikannya ke masyarakat atau pihak-pihak lain yang berkepentingan; dan (3) berkompetisi dengan penerbitan e-proceeding dan membangun repositori lembaga guna meningkatkan aksesibilitas informasi dan webometrik lembaga. Perdananugraha (2012) mengatakan bahwa webometrik merupakan suatu alat pengukuran/pemeringkatan situs-situ (website) yang dimiliki oleh penyelenggara pendidikan tinggi dan institusi riset di seluruh dunia. Tujuan dari pemeringkatan ini untuk mengetahui seberapa besar dukungan suatu institusi pendidikan/riset terhadap eksistensinya di dunia maya atau internet. salah satu pemeringkatan website lembaga ilmiah yang dinilai berdasarkan empat aspek, yaitu ukuran (size), keterlihatan (visibility), keragaman informasi (rich files), dan cendekia (scholar). Tujuan dari pemeringkatan website di lembaga ilmiah yaitu untuk mempromosikan publikasi ilmiah yang dilakukan lembaga penelitian melalui internet. Keterbukaan dan kemudahan publik mengakses publikasi ilmiah dan materi akademik melalui internet menjadi sasaran utama pemeringkatan webometrik (Tempo, 2012). Publikasi ilmiah yang dapat diakses melalui internet ini dianggap lebih mudah dan menjamin tingginya standar kualitas publikasi ilmiah yang dibaca publik.

\section{d. Pengelolaan E-Conference dengan OCS}

OCS adalah aplikasi open source yang dirancang khusus untuk penerbitan elektronik (e-publishing) hasil konferensi secara lengkap, termasuk memfasilitasi proses penerbitan dan peer-review. OCS dikembangkan oleh Public Knowledge Project (PKP), yaitu suatu lembaga nirlaba internasional yang memiliki inisiasi untuk pengembangan software e-publishing open source dan gratis melalui proyek penelitian dalam rangka peningkatan mutu penerbitan ilmiah. Pengembangan OCS diawali dari kegiatan penelitian dan pengembangan yang diinisiasi oleh PKP di the University of British Columbia. OCS dirilis sebagai open source software pada tahun 200 dan di tahun 2007 rilis OCS 
versi 2.0. Aplikasi OCS untuk kegiatan $e^{-}$ conference dapat diakses dan di-download melalui situs PKP di https://pkp.sfu.ca/ocs/ (Gambar 10).

\section{PKP PROJEC}

Open Conference Systems

Sept 20: What's next for OCS? Help us decide by responding to this briet survey.

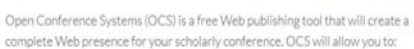

- create a conference Web site

- compose and send a call for popers

- allow paper submitters to edit their work

Gambar 10. Situs OCS - PKP (sumber: https://pkp.sfu.ca/ocs/)

Beberapa fasilitas yang ada di OCS, antara lain: (1) membuat situs konferensi; (2) menyusun informasi dan mengirim naskah call for paper (abstrak atau full text); (3) memberikan persetujuan penerimaan abstrak dan makalah; (4) melakukan perbaikan naskah (editing) secara elektronik; (5) menelusuri hasil pengiriman surat (email) dan naskah; (6) mem-posting data asli (jika diinginkan); (7) meregistrasi peran anggota (peserta, reviewer, atau event organizer); dan (8) mengintegrasikan diskusi online pascakonferensi. Tampilan "demo" penggunaan OCS untuk pengelolaan $e$ conference dapat diakses di: https://pkp.sfu.ca/conferences (Gambar $11)$.

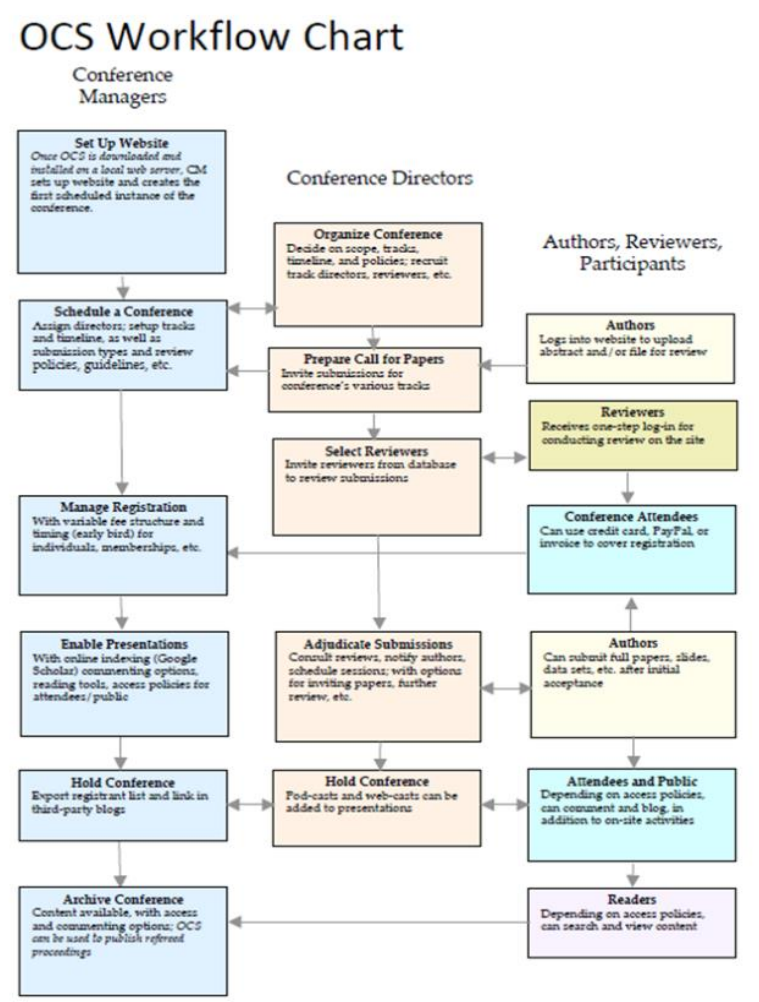

Gambar 12. OCS Workflow Chart (PKP, 2008)

Mengacu pada tahapan pengelolaan $e$ conference di atas, penyelenggara konferensi dapat menunjuk seorang administrator situs (site administrator) dan/atau manajer konferensi (conference manager) untuk melakukan pengembangan dan pengelolaan sistem $e$ conference dengan OCS, Berikut ini hal-hal yang perlu diperhatikan oleh penyelenggara konferensi, administrator situs, dan manajer konferensi dalam pengelolaan e-conference dengan OCS.

1) Memahami ketentuan operasional OCS, yang mencakup sistem operasi, persyaratan sistem, keamanan sistem, bahasa, dan kebijakan submit (bagian dari penerbitan makalah/prosiding). Hal tersebut dijelaskan pada Tabel 5. 
Tabel 5. Deskripsi Operasional OCS

\begin{tabular}{|c|c|}
\hline Hal & Deskripsi \\
\hline $\begin{array}{l}\text { Sistem } \\
\text { Operasi }\end{array}$ & $\begin{array}{l}\text { - Open source e-publishing di bawah lisensi GNU General Public } \\
\text { License, pengguna dapat menyalin dan digunakan sesuai kebutuhan; } \\
\text { - Sistem single conference dan multiple conferences; } \\
\text { - Sistem penjadwalan "scheduled conference"; } \\
\text { - Aplikasi OCS download di https://pkp.sfu.ca/ocs/ocs_download/; }\end{array}$ \\
\hline $\begin{array}{l}\text { Persyaratan } \\
\text { sistem }\end{array}$ & $\begin{array}{l}\text { - } \mathrm{PHP}>=4.2 . x \text { (including PHP 5.x); Microsoft IIS requires PHP 5.x; } \\
\text { - MySQL >= 3.23.23 (including MySQL 4.x) or PostgreSQL >= } 7.1 \\
\text { (including PostgreSQL 8.x); } \\
\text { - Apache >=1.3.2x or >=2.0.4x or Microsoft IIS 6; } \\
\text { - Operating system: Any OS that supports the above software, } \\
\text { including Linux, BSD, Solaris, Mac OS X, Windows; }\end{array}$ \\
\hline & 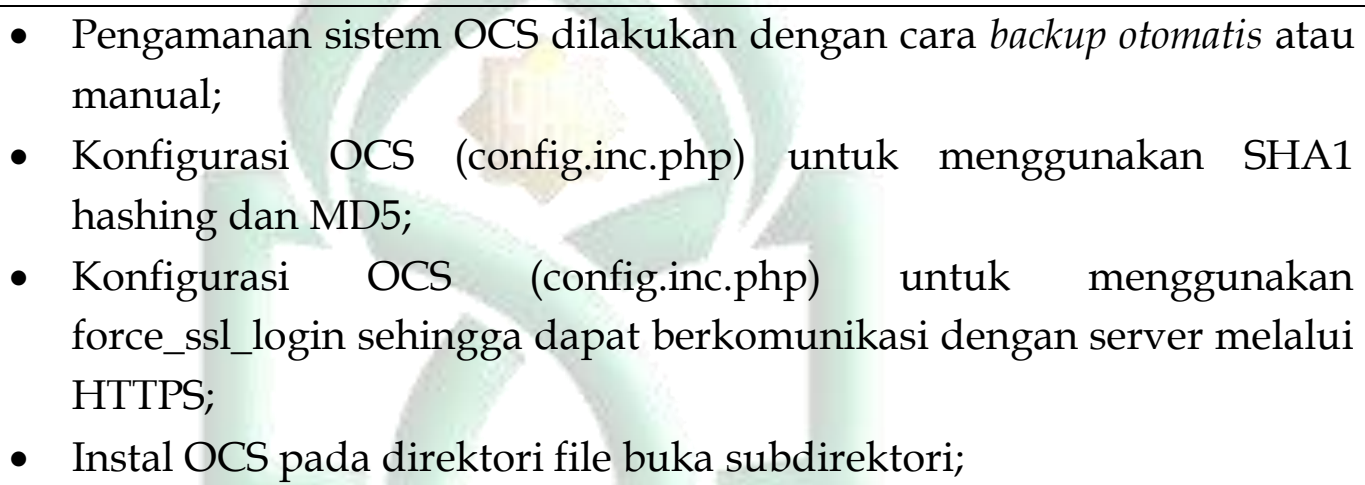 \\
\hline Bahasa & $\begin{array}{l}\text { - OCS memiliki sistem multibahasa, yang memungkinkan dapat } \\
\text { mempublikasikan kegiatan konferensi dalam berbagai bahasa dan } \\
\text { penambahan bahasa untuk penerbitan prosiding konferensi dalam } \\
\text { dua atau tiga bahasa; } \\
\text { - Pengembangan language supporting ini berdasarkan kegiatan proyek } \\
\text { penelitian Tim OCS dengan kategori: lengkap (complete), sebagian } \\
\text { lengkap (partially complete), dan tidak termasuk (not included); }\end{array}$ \\
\hline $\begin{array}{l}\text { Kebijakan } \\
\text { submit }\end{array}$ & $\begin{array}{l}\text { - Submit abstrak (abstract-only); } \\
\text { - Submit makalah (paper-only)' } \\
\text { - Submit abstrak dan makalah dengan sekaligus review; } \\
\text { - Submit abstrak kemudian makalah dengan sistem review terpisah. }\end{array}$ \\
\hline
\end{tabular}

Sumber: https://pkp.sfu.ca/ocs/

2) Menetapkan tim pelaksana kegiatan konferensi, baik tim teknis maupun tim editorial prosiding. Tim teknis ini biasanya disebut panitia atau event organizer, seperti ketua panitia; sekretariat; bendahara; dan seksi-seksi, seperi seksi acara; dokumentasi; akomodasi; dan konsumsi. Sedangkan tim editorial adalah mereka yang bertanggung jawab atas kualitas makalah dan penerbitan prosiding, seperti pemimpin redaksi (editor-in- 
chief); editor; reviewer; layouter; dan sekretaris redaksi. Penetapan tim pelaksana konferensi sebaiknya memperhatikan aspek lingkup, tujuan, dan jumlah peserta konferensi. Sedangkan tim editorial setidaknya mereka yang memahami kaidahkaidah publikasi ilmiah; memiliki bidang kepakaran ilmu yang jelas; dan memiliki rekam jejak publikasi ilmiah yang jelas.

3) Menyusun pedoman kebijakan penerbitan prosiding. Pedoman ini berfungsi sebagai panduan teknis pengisian konten situs konferensi dan bukti komitmen dari penyelenggara konferensi dan tim editorial dalam penerbitan prosiding. Berikut ini isi kebijakan penerbitan prosiding (Nashihuddin, 2016).

$>$ Bagian 1: Sekilas kegiatan (deskripsi);

$>$ Bagian 2: Identitas terbitan.

$>$ Bagian 3: Kebijakan penerbitan $\rightarrow$ kebijakan review; hak cipta; privasi; langganan; fokus dan lingkup; kebijakan review; registrasi pengguna;

> Bagian 4: penyerahan naskah; bagian prosiding; petunjuk penulisan; persyaratan submit makalah;

> Bagian 5: editorial naskah; instruksi copy edit; instruksi layout; instruksi proofread;

> Bagian 6: etika publikasi naskah; etika penulis; etika editor; etika reviewer; etika pengelola terbitan;

> Bagian 7: informasi penerbitan; informasi untuk pembaca; informasi untuk penulis;

$>$ Bagian 8: Tugas editorial; koordinator/ketua konferensi; directors/ secretariats; track directors/ copy editors; reviewer; layouter/ desain grafis; administrator/it supporting;
Bagian 9: penutup; dan disertai lampiran-lampiran: form checklist review makalah; form call for reviewer loknas; form penilaian kinerja reviewer; template makalah loknas.

4) Menginstal OCS. Administrator situs melakukan instalasi aplikasi OCS dengan versi OCS yang tersedia di situs

PKP

(https://pkp.sfu.ca/ocs/ocs_downloa d/). Setelah menginstal OCS di server online, tugas administrator situs berikutnya adalah mengelola informasi situs, seperti alamat URL situs; nama situs konferensi; judul konferensi (redirect); deskripsi situs (sekilas); default bahasa situs; kontak email admin; jumlah karakter password; stylesheet situs; alamat OAI situs; dan fungsi administrasi situs yang lain. Berikut ini tampilan situs konferensi sesi manajemen situs di OCS (Gambar 13).

\section{LOKAKARYA NASIONAL DOKUMENTASI DAN INFORMASI}

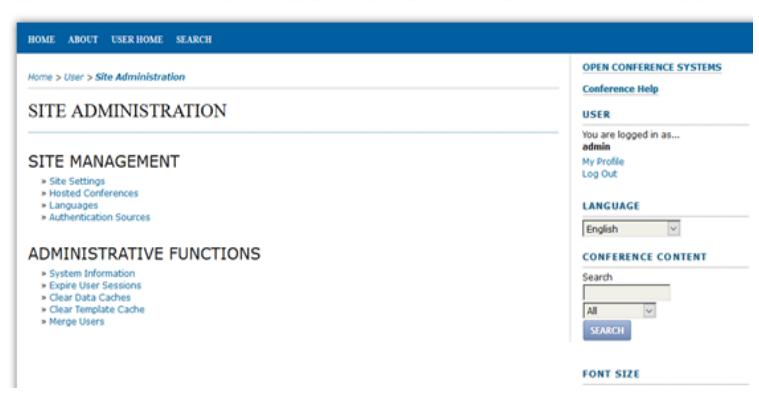

Gambar 13. Tampilan fitur manajemen situs dengan OCS (Sumber: Simulasi OCS di Server Offline)

5) Mengelola konten situs konferensi. Pengelolaan konten situs konferensi dilakukan oleh manajer konferensi. Pengelolaan konten situs ini sebaiknya mengacu pada kebutuhan informasi terkini penyelenggaran konferensi dan pedoman kebijakan penerbitan 
prosiding. Pengisian konten situs konferensi berdasarkan pedoman kebijakan penerbitan prosiding. Berikut ini tampilan situs konferensi sesi manajemen konten di OCS (Gambar 14).

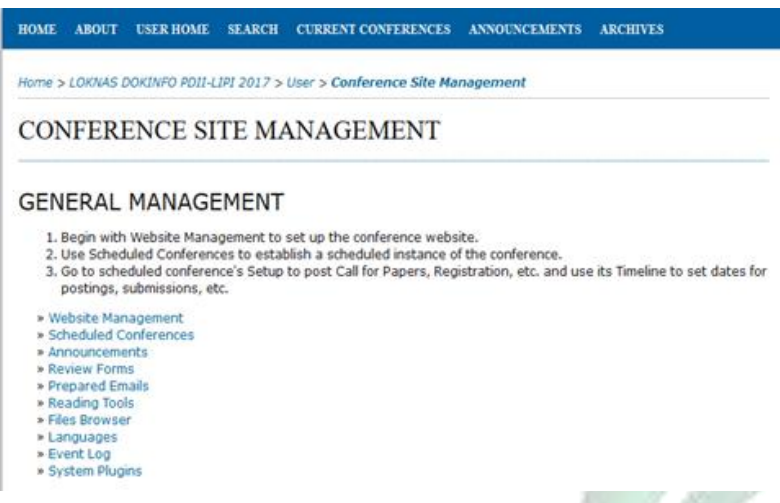

\section{CURRENT CONFERENCES}

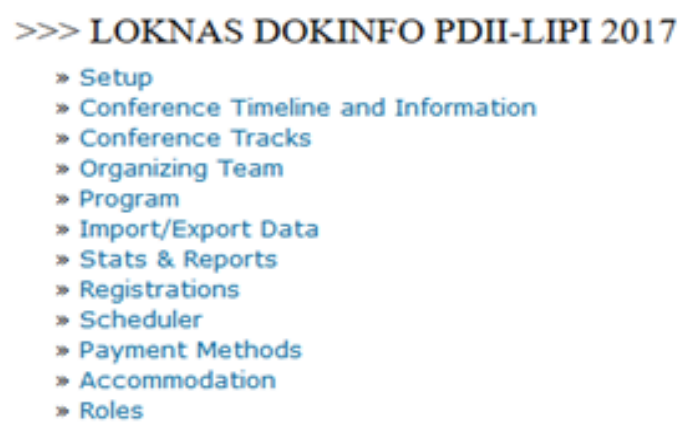

\section{ROLES}

$\gg$ Directors

- Track Directors

- Reviewers

* Authors

* Readers

\section{ROLES}

» Directors

» Track Directors

》 Reviewers

» Authors

» Readers

\section{USERS}

»All Enrolled Users

» Enroll a User from this Site in this Conference

»Create New User

» Merge Users

\section{ROLES}

»Conference Managers

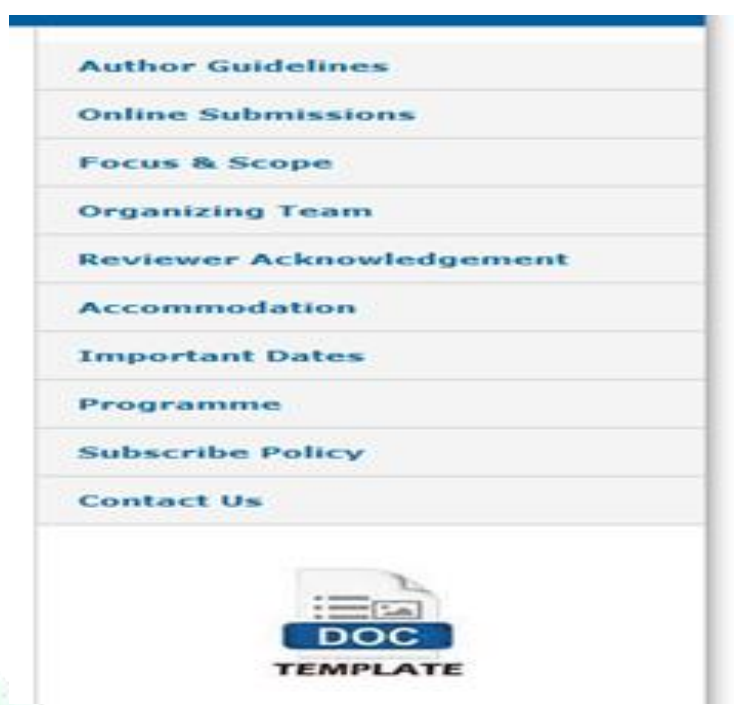

Gambar 14. Tampilan fitur manajemen konten dengan OCS (Sumber: Simulasi OCS di Server Offline)

6) Menetapkan penjadwalan konferensi (time line) untuk informasi call for paper. Penjadwalan ini dilakukan oleh manajer konferensi atau sekretariat konferensi, yang mencakup:

- Pelaksanaan konferensi $\rightarrow$ tanggal hari pertama dan hari terakhir konferensi;

Informasi website $\rightarrow$ tanggal publikasi konferensi terkini dan pengarsipan publikasi;

Submit naskah $\rightarrow$ tanggal pembukaan dan penutupan registrasi pemakalah; posting call for paper; persetujuan submit; dan penutupan submit makalah;

Review $\rightarrow$ tanggal pembukaan dan penutupan registrasi reviewer;

Posting website $\rightarrow$ tanggal penerimaan abstrak; penjadwalan daftar informasi konferensi; dan persetujuan makalah.

Penetapan jadwal konferensi pada OCS dapat dilihat pada Gambar 15. 


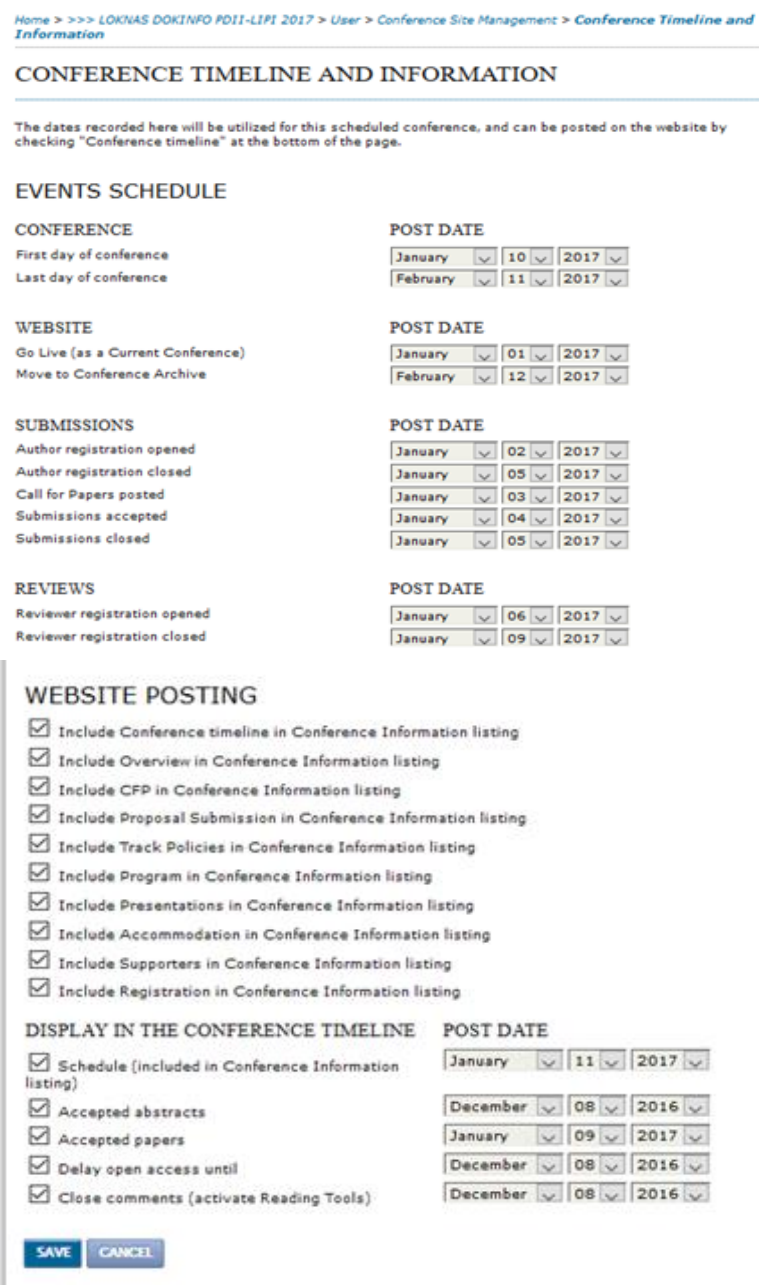

Gambar 15. Tampilan fitur penjadwalan konferensi dengan OCS (Sumber: Simulasi OCS di Server Offline)

7) Mempromosikan penyelenggaraan konferensi dan prosiding hasil konferensi. Promosi dapat dilakukan melalui media sosial atau media masa, baik cetak maupun elektronik/online.

8) Mengevaluasi pelaksanaan kegiatan konferensi. Evaluasi ini dilakukan secara menyeluruh, dalam hal: (a) persiapan, proses pelaksanaan, hingga akhir kegiatan konferensi; penerbitan prosiding dan diseminasi terbitan; dan (c) pemantauan pengakses informasi prosiding di situs konferensi. Terkait dengan pemantauan jumlah pengakses situs konferensi, administrator situs atau manajer konferensi dapat memasang sistem statistic counter otomatis (Google Analytic; Stat Counter; Flag Counter, dsb.) dan database pengindeks ilmiah global (Google Scholar) pada situs konferensi.

\section{KESIMPULAN}

Berdasarkan hasil dan pembahasan di atas dapat disimpulkan bahwa untuk mengembangkan kegiatan konferensi, seminar, dan pertemuan ilmiah sejenisnya sistem online diperlukan upaya keras dan komitmen yang kuat dari pemerintah dan penyelenggara

konferensi. Penyelenggaraan konferensi dengan sistem e-conference dan online ini dianggap jauh lebih efektif, baik dalam hal keterlibatan partisipan konferensi (peserta, pemakalah, dan pihak lain yang berkepentingan); peningkatan kualitas naskah call for paper; maupun peningkatan kerjasama/kolaborasi penelitian antarpersonal atau institusi di lembaga ilmiah. Dalam mengelola e-conference, pihak penyelenggara harus menyiapkan segala sumber daya organisasi yang dimiliki dan memperhatikan segala ketentuan dan kaidah-kaidah - publikasi ilmiah agar prosiding yang dihasilkan berkualitas dan berdampak bagi pengembangan iptek di masyarakat. Penyelanggara konferensi atau pengelola e-conference ini sebaiknya memperhatikan lingkup konferensi dan ketentuan penerbitan prosiding, baik untuk skala nasional maupun internasional. Selain itu, untuk meningkatkan penerbitan e-proceeding di Indonesia, pemerintah dan penyelenggara konferensi perlu berupaya keras dan memiliki komitmen yang tinggi untuk menggalakan penyelenggaraan $e$ conference dan penerbitan e-proceeding. Diharapkan dengan memanfaatkan OCS sebagai situs konferensi dan mengelola 
kegiatan e-conference, kualitas dan reputasi terbitan prosiding di Indonesia semakin lebih baik dan menjadi output lembaga yang dapat dibanggakan. Sebagai penutup, penulis menyarankan kepada institusi pendidikan dan lembaga litbang yang setiap tahunnya menyelenggarakan konferensi, seminar, atau pertemuan ilmiah sejenisnya agar memanfaatkan OCS untuk penyelenggaranaan $e$ conference dan penerbitan e-proceeding, terima kasih.

\section{DAFTAR PUSTAKA}

Dirjen-DIKTI. (2014). Pedoman Operasional Penilaian Angka Kredit Kenaikan Pangkat/Jabatan Akademik Dosen. Jakarta

Kemenristek-DIKTI. (2015). Surat Edaran Kemenristek-DIKTI Nomor 193/E/SE/XII/2015 _ tentang Akreditasi Jurnal Ilmiah Secara Elektronik. Jakarta.

LIPI Press. (2014). Pedoman Penerbitan Buku LIPI Press. Jakarta.

LIPI. (2012). Pedoman Karya Tulis Ilmiah Peraturan Kepala Lembaga Ilmu Pengetahuan Indonesia Nomor 04/E/2012. Jakarta.

LIPI. (2014). Peraturan Kepala Lembaga Ilmu Pengetahuan Indonesia Nomor 2 Tahun 2014 Tentang Petunjuk Teknis Jabatan Fungsional Peneliti. Jakarta.

Lukman. (2016). Policy Brief: Kebijakan EJournal, Akreditasi, Indeksasi, Sitasi, dan Internasionalisasi Jurnal di Indonesia (Unpublished Paper). Jakarta: KemenristekDIKTI.

Magrill, R. M., dan Hickey, D. J. (1984). Acquisitions Management and Collection Development in Libraries. Chichago: American Library Association.

Muchtar, R., dan Thoha, M. (2012). Teknik Penulisan Karya Tulis Ilmiah
(Bidang IPS), Edisi Revisi. Cibinong: Pusbindiklat Peneliti LIPI.

Nashihuddin, W. (2016). Pedoman Penerbitan Prosiding Lokakarya Nasional Dokumentasi Dan Informasi (Unpublished Paper). Jakarta.

Perdananugraha, G. M. (2012). Studi Kasus \& Pembelajaran Penurunan Peringkat Webometrics Pada Lembaga Ilmu Pengetahuan Indonesia Periode 2012. Makalah Seminar Nasional Aplikasi Teknologi Informasi 2012 (SNATI 2012), Yogyakarta, 15-16 Juni.

PKP. (2008). OCS in an Hour An Introduction to Open Conference Systems Version 2.1. on https://pkp.sfu.ca/files/OCSinan Hour.pdf (4 Februari 2017).

PKP - (2008). OCS Quick Guide: For OneTime Events and Director-Based Reviews. on https://pkp.sfu.ca/files/OCS_Qui ckGuide.pdf (4 Februari 2017).

PKP. (2008). OJS/OCS Quick Reference-Version 1.0. on https://pkp.sfu.ca/files/docs/quic kreference/quickreference.pdf (6 Februari 2016).

Reitz, J. M. (2014). ODLIS: Online Dictionary of Library and Information Science. Di http://www.abcclio.com/ODLIS/odlis_c.aspx Februari 2017).

Tempo.

(2012)

https://m.tempo.co/read/news $/ 2$ 012/08/02/061420857/lipi-masuk100-lembaga-penelitian-terbesardunia-- LIPI Masuk 100 Lembaga Penelitian Terbesar Dunia (4 Februari 2017). 